\title{
Feed mills operation and feedstuff safety in Oyo zone, Nigeria Okunlola, O. O.
}

\author{
Department of Agricultural Education, School of Vocational and Technical Education, \\ (x) \\ The College of Education, Lanlate \\ Corresponding author: *greenfields2012@gmail.com
}

\section{Abstract}

Feed mills play a vital role in the success of the livestock industry. Feed mills operation in Oyo zone of Oyo state, Nigeria is as old as the livestock industry in the zone. However, very little information on the activities of the feed mills in the zone is available. This study was therefore carried out to elicit information on the activities of the feed mills in Oyo zone, Nigeria. A multistage sampling method was adopted for this study. In the first stage, Oyo zone was divided into four, while in the second stage 10 questionnaires were administered to feed millers in each of the four Local Government Areas (LGAs), making a total of 40 in all. All administered questionnaires were recovered, processed and subjected to descriptive statistics using frequency counts and percentages. From the result obtained, majority of the respondents had tertiary education (70.00\%) and $65.00 \%$ of them were casual workers. The study also shows that majority of the feed mills in the study area were for commercial purposes (70.00\%) and semi-automated (65.00\%). Also, 67.50 claimed they had separate structures where they stored the feed ingredients and feeds and $72.50 \%$ of the feed millers claimed awareness of mycotoxins in feed ingredients and feeds. The study reveals that majority of the respondents financed their feed mill businesses through their personal savings $(40.00 \%)$. It can be recommended that low interest credit facilities be provided to the feed millers by the concerned authorities to further boost their businesses.

Keywords: Feed mill, livestock industry, Oyo zone, feedstuffs, feed safety

\section{L'Operation des usines d'aliments des animaux et La sécurité alimentaire des animaux dans la zone d'Oyo, Nigéria}

Okunlola, O. O.

Department of Agricultural Education, School of Vocational and Technical

Education,

The College of Education, Lanlate

Corresponding author: * greenfields2012@gmail.com

\section{Résumé}

$\overline{\text { Les usines d'aliments des animaux jouent un rôle essentiel dans le succès de l'industrie de }}$ l'élevage. L'operation des usines d'aliments des animaux dans la zone d'Oyo de l'État d'Oyo, au Nigéria, est aussi ancienne que l'industrie de l'élevage dans la zone. Cependant, très peu d'informations sur les activités des meuneries de la zone sont disponibles. Cette étude a donc été réalisée pour obtenir des informations sur les activités des usines d'aliments des animaux dans la zone d'Oyo, au Nigeria. Une méthode d'échantillonnage à plusieurs degrés a été adoptée pour cette étude. Dans la première étape, la zone d'Oyo a été divisée en quatre, tandis que dans la deuxième étape, 10 questionnaires ont été administrés aux minotiers dans chacune des quatre zones de gouvernement local (LGA), pour faire un total de 40. Tous les questionnaires administrés ont été récupérés, traités et soumis à des statistiques descriptives utilisant des comptages de fréquence et des pourcentages. D'après le résultat obtenu, la 


\section{Feed mills operation and feedstuff safety in Oyo zone, Nigeria}

majorité des répondants avaient une formation supérieure (70,00\%) et 65,00\% d'entre eux étaient des travailleurs occasionnels. L'étude montre également que la majorité des meuneries de la zone d'étude étaient à des fins commerciales (70,00\%) et semi-automatisées (65,00\%). En outre, 67,50 ont déclaré qu'ils avaient des structures séparées où ils stockaient les ingrédients et les aliments des animaux et 72,50\% des fabricants d'aliments des animaux ont déclaré qu'ils étaient conscients des mycotoxines présentes dans les ingrédients et les aliments des animaux. L'étude révèle que la majorité des répondants ont financé leurs activités de meunerie grâce à leurs économies personnelles (40,00\%). Il peut être recommandé que les autorités concernées fournissent des facilités de crédit à tauxfaible aux meuneries afin de stimuler davantageleurs activités.

Mots clés : Usine d'aliments des animaux, industrie de l'élevage, zone Oyo, aliments des animaux, sécurité alimentaire

\section{Introduction}

Feed mill operation and livestock farming are intricately linked together as the success of any livestock enterprise depends on the nutritional management of such and other factors. Feed accounts for not less than $70 \%$ of the total cost of livestock production. This high cost of feed has been attributed to be a major factor responsible for the slow growth of the livestock industry in Nigeria. Odunsi et al. (2008) stated that the feed cost is as important as the procurement cost of the livestock. The authors further affirmed that there is a positive correlation between livestock production efficiency and the economic efficiency of the feed mill industry, due to the large percentage of the feed cost in the livestock production cost. This shows that the place of quality feed in the right quantity at an efficient cost cannot be down played in any successful livestock enterprise. The Nigerian animal feed sector has been estimated to be worth over 2 billion dollars and it's still expanding (Global Agricultural Information Network, 2019). Also, Food and Agricultural Organization (2019) stated that an urbanized and affluent Nigerian population will, in the near future, demand for healthier animal food sources. However, the poultry industry, which is a major consumer of livestock feeds experienced negative growth during the economic recession that started in 2016, in which the Nigeria
Bureau of Statistics (2016) claimed Nigeria's economy contracted by 0.36 and $2.06 \%$ in the $1^{\text {st }}$ and $2^{\text {nd }}$ quarters of the year, as many farms were either closed down or performed minimal operations, which invariably impacted the feed mill industry negatively. Feedstuffs are processed and compounded using specific feed formulas for the different livestock types, taking into considerations the age, physiological status, cost of processing and other factors. The feed mill industry services the production of different species of livestock which include poultry, piggery, rabbitry, fishery, even ruminants which utilize compounded feeds as supplementary to their regular feeding regimes. The history of feed mill in Nigeria can be traced to the University of Ibadan which established a small feed mill unit in 1951. This success story was later built on by the government of Western Nigeria, which established three feed mills to service the growing livestock industry in the region, and Pfizer, which established the first commercial feed mill in Nigeria, in 1961 and 1963 respectively (Akintayo, 1989 and Livestock farmer, 1987, as cited by Ademuyiwa et al. (2014). Feed mills are established to meet the demands of livestock enterprises by producing compounded feed that meet $90 \%$ of their daily nutrient requirements at least 95\% of the times (Odunsi et al., 2008). Feed mills in Nigeria are faced with certain 


\section{Okunlola}

problems which have great impact on the business. Such problems include feed ingredients availability and cost. Mostly, the grains used as energy and protein sources for livestock by the feed millers also serve man as staple foods. This invariably brings a lot of competition between man and his livestock which makes the prices of such feed ingredients to skyrocket, thereby translating into increased feed cost and the cost of livestock products. For instance, maize constitutes the largest components of livestock feeds, especially in this part of the world, which puts a lot of pressure on the availability and cost of the feed ingredients (The Poultry Site, 2016). Also, the ban on importation of poultry products by the Obasanjo government in 2003, which was not enforced until 2015 (Global Trade Alert, 2015), further put pressure on the feed mill industry in order to be able to meet the demand of the growing poultry industry. This also had ripple effects on the cost and availability of feed ingredients for the feed mill industry and feedstuffs for man's consumption. The increasing growth of the livestock industry, since the Obasanjo regime in Nigeria, has led to the establishments of many Small and Medium Scale (SMS) feed mills in the country in general and Oyo zone of Oyo state of Nigeria, in particular in order to meet up with the increasing demands for compounded feeds from the livestock industry. The purpose of this study was to determine the activities of the feed millers and feedstuff safety in Oyo zone of Oyo state, Nigeria. Data collected include the bio data of respondents, feed mill operations, feedstuffs and feed storage and mycotoxin awareness by the feed millers, and the financial position of the feed mills.

\section{Materials and methods}

This study was carried out in Oyo zone of Oyo state, Nigeria. The study area has four
Local Government Areas (LGAs), namely, Oyo East, Oyo West, Atiba and Afijio with headquarters at Kosobo, Ojongbodu, OfaMeta and Jobele respectively. The population of Oyo zone is 576,872 and a landmass of $6,579.023 \mathrm{~km}^{2}$ (Oyo State, 2019). The people of the zone traditionally engaged in agriculture and crafts such as wood and calabash carving. The zone has a very large concentration of livestock farms, especially poultry which patronize the various feed mills in the zone. A multistage sampling method was adopted for this study. In the first stage, Oyo zone was divided into four on basis of LGAs, while in the second stage, 10 questionnaires were administered to the feed millers in each of the LGAs, making a total of 40 in all. All administered questionnaires were recovered, processed and subjected to descriptive statistics using frequency counts and percentages. Data collection covered vital aspects of the respondents such as bio data of respondents, feed mill operations, storage of feedstuffs and feed, and feed mill finance.

\section{Results and discussion}

Table 1 shows the bio data of the respondents. From the table, majority of the respondents were male $(85.00 \%)$ and had tertiary education $(70 \%)$. Also, the table shows that majority of the respondents were managers at work $(60 \%)$ while $65.00 \%$ of them were casual workers. Also, $50.00 \%$ of the respondents were within the age range of $20-39$ years while $60 \%$ of them were less than 10 years on the job. This result indicates that majority of the businesses were in their infancy. Casualization of the workers is a management strategy usually employed by Small and Medium Scale Enterprises (SMSEs) in order to keep afloat in the turbulent business terrain in Nigeria as this will lessen their burden of pension and gratuity payments upon the disengagement of such staff members. 


\section{Feed mills operation and feedstuff safety in Oyo zone, Nigeria}

Also, the educational status of the respondents is an indication of their ability to adopt new and productive strategies in improving their businesses. The age range of majority of the respondents showed their ability to be able to withstand the rigor of the job as it is energy consuming.

Table 1: Bio data of feed mill operators

\begin{tabular}{llll}
\hline Item & Criterion & No. & \% \\
\hline Sex & Male & 34 & 85.00 \\
Age (years) & Female & 6 & 15.00 \\
& $<20$ & 4 & 10.00 \\
Educational status & $20-39$ & 20 & 50.00 \\
& $40-59$ & 16 & 40.00 \\
Position at work & Secondary & 12 & 30.00 \\
& Tertiary & 28 & 70.00 \\
& Manager & 24 & 60.00 \\
Work status & Mill attendant & 8 & 20.00 \\
Length of service & Feed store keeper & 3 & 7.50 \\
(years) & Accountant & 5 & 12.50 \\
& Casual & 26 & 65.00 \\
& Permanent & 14 & 35.00 \\
& $<10$ & 24 & 60.00 \\
Table 2 shows & $10-19$ & 12 & 30.00 \\
& $20-39$ & 04 & 10.00 \\
\hline
\end{tabular}

Table 2 shows the feed mill operation in the study area. Data from the table shows that majority of the feed mills in the study area were for commercial purposes $(70.00 \%)$ and semi-automated $65.00 \%$ ) in operation. The table also reveals that majority of the feed mills had a workforce range of $1-10$ people $(85.00 \%)$ and work between $1-5$ hours on working days $(70.00 \%)$. As regards their production capacities, $50.00 \%$ of the feed mills produced between $10-19$ tons of feeds weekly while $82.50 \%$ of them depended on national grid, supplemented by electric generating sets as their power sources. Majority of the feed mills under this study were small scale businesses as reflected by their production capacity and number of their employees. This report was corroborated by Ademuyiwa et al. (2014), who reported that $56 \%$ of the feed mills in the Southwestern Nigeria were small scale businesses. Also, their choice of power source may be informed by the fact that the national grid is cheaper than any other source of power in the country
Table 3 shows the feed ingredients, feed storage and mycotoxin awareness by feed millers. From the table, $67.50 \%$ of the respondents claimed they got supplies of feed ingredients from sellers and $62.50 \%$ claimed they had specific structures where they stored the feed ingredients and feedstuffs separately. Also, $72.50 \%$ of the feed millers claimed awareness of mycotoxins in feed ingredients and feeds and $50.00 \%$ claimed they got the awareness through the farmers' feedback on the performances of the livestock fed with feed purchased from the feed millers. The table also reveals that the feed millers $(79.31 \%)$ adopted the purchase of wholesome feed ingredients in reducing the incidence of mycotoxins in feeds produced by them. Concerning the effects of mycotoxins on the businesses, $50 \%$ of the respondents indicated poor sales as the major effect. Since many of the respondents got supplies of feedstuffs from known sources unlike when bought from the markets, it would be easy to trace the source of any problem with 


\section{Okunlola}

the feedstuffs purchased. Having specific structures for feedstuffs and feed storage would further enhance the shelf life of such through proper store management unlike when left in the open or production area without any specific storage facility. The high level of awareness of mycotoxins, their understanding of the effects and management strategies against it, in feedstuffs and feeds can be linked with the high level of education of the feed millers. .

Table 2: Feed mill operation in the study area

\begin{tabular}{|c|c|c|c|}
\hline Item & Criterion & No. & $\%$ \\
\hline \multirow[t]{3}{*}{ Type of feed mill } & Private & 3 & 7.50 \\
\hline & Commercial & 28 & 70.00 \\
\hline & Dual purpose & 9 & 22.50 \\
\hline \multirow[t]{3}{*}{ Operation type } & Manual & 12 & 30.00 \\
\hline & Automated & 2 & 5.00 \\
\hline & Semi-automated & 26 & 65.00 \\
\hline \multirow{2}{*}{ Staff strength } & $1-10$ & 34 & 85.00 \\
\hline & $11-20$ & 6 & 15.00 \\
\hline Average Operation & $1-5$ & 28 & 70.00 \\
\hline hours per day & $6-10$ & 12 & 30.00 \\
\hline \multirow[t]{3}{*}{ Source of power } & National grid & 3 & 7.50 \\
\hline & Electric Generator & 12 & 30.00 \\
\hline & National grid and electric generator & 25 & 82.50 \\
\hline \multirow{4}{*}{$\begin{array}{l}\text { Production per week } \\
\text { (tons) }\end{array}$} & $1-9$ & 5 & 12.50 \\
\hline & $10-19$ & 20 & 50.00 \\
\hline & $20-39$ & 12 & 30.00 \\
\hline & 40 above & 3 & 7.50 \\
\hline
\end{tabular}

Table 3 : Feed ingredients, feed storage and mycotoxin awareness by feed millers

\begin{tabular}{|c|c|c|c|}
\hline Item & Criterion & No & $\%$ \\
\hline \multirow[t]{3}{*}{ Source of feed ingredients } & Purchase from local markets & 12 & 30.00 \\
\hline & Supplies & 27 & 67.50 \\
\hline & Personal farm & 1 & 2.50 \\
\hline \multirow{2}{*}{$\begin{array}{l}\text { Feedstuffs and feed Storage } \\
\text { facilities }\end{array}$} & Yes & 25 & 62.50 \\
\hline & No & 15 & 37.50 \\
\hline \multirow{2}{*}{$\begin{array}{l}\text { Storage of feed after } \\
\text { processing (weeks) }\end{array}$} & $1-2$ & 28 & 70.00 \\
\hline & $3-4$ & 12 & 30.00 \\
\hline \multirow{3}{*}{$\begin{array}{l}\text { Awareness of mycotoxins in } \\
\text { feed ingredients and feeds } \\
\text { Source of information }\end{array}$} & Yes & 29 & 72.50 \\
\hline & No & 11 & 27.50 \\
\hline & Radio/ Television & 3 & 7.50 \\
\hline & Farmers & 20 & 50.00 \\
\hline & Feed sellers & 17 & 42.50 \\
\hline \multirow{3}{*}{$\begin{array}{l}\text { How do you handle mycotoxin } \\
\text { in feeds }(\mathrm{n}=29)\end{array}$} & Toxin binders & 2 & 6.90 \\
\hline & Good feed storage & 4 & 13.79 \\
\hline & $\begin{array}{l}\text { Purchase of wholesome feed } \\
\text { ingredients }\end{array}$ & 23 & 79.31 \\
\hline \multirow{3}{*}{$\begin{array}{l}\text { Any effect of mycotoxin } \\
\text { handling on your business" }\end{array}$} & Increased production cost & 8 & 20.00 \\
\hline & Poor sales & 20 & 50.00 \\
\hline & No effect & 12 & 30.00 \\
\hline
\end{tabular}


Table 4: Feed mill finance

\begin{tabular}{llll}
\hline Item & Criterion & No. & \% \\
\hline Average weekly & 100,000 & 6 & 15.00 \\
running cost ( & $100,000-490,000$ & 21 & 52.00 \\
& $500,000-1,000,000$ & 8 & 20.00 \\
& $>1,000000$ & 5 & 12.50 \\
Average weekly & $100,000-490,000$ & 20 & 50.00 \\
income (f) & $500,000-1,000,000$ & 14 & 35.00 \\
Source of finance & Personal savings & $1,000,000$ & 15.00 \\
& Loan from family and friends & 3 & 40.00 \\
& Bank loan & 6 & 7.50 \\
& Loans from Cooperative societies & 15 & 15.00 \\
\hline
\end{tabular}

Table 4 shows information on the finance of the feed mills in the study area. The study reveals that $52 \%$ of the respondents had an average weekly running cost of between $100,000-490,000$ naira while the average weekly income was between 100,000 $490,000(50.00 \%)$. Also, majority of the respondents financed their feed mill businesses through their personal savings $(40.00 \%)$. Considering the financial flow of the feed mills under this study, it is reflective of the fact that they were small scale enterprises.

\section{Conclusion}

This study showed that majority of the feed mills in Oyo zone of Oyo state, Nigeria could be classified as small scale enterprises based on their financial status, status of workers on their employ and operation type. The study also revealed that majority of the feed millers were aware of mycotoxins in feedstuffs and feeds and took specific efforts in preventing such in their products. It is therefore recommended that the activities of the feed millers in the study area be regulated by the concerned ministries, departments and agencies of government for improved productivities.

\section{References}

Ademuyiwa, M. A., Gbenga, T. A. and Lawrence, A. A. 2014. Nigeria Economic Analysis of Feedmill
Industries in Ogun and Oyo states, Southwest of Nigeria. Researchjournali's Journal of Entrepreneurship. Vol. 2(3), 1-10.

Food and Agricultural Organization 2019. Africa sustainable livestock 2050, transforming livestock sector. Nigeria what do long-term projections mean"

Global Agricultural Information Network 2019. Nigeria feed sector snapshot - 2019. GAIN report NG19005.

Global Trade Alert 2015. Nigeria enforcement of import ban on p o u l t r y p r o d u c e . Https://www.globaltradealert.org/i ntervention/20500/importban/nigeria-enforcement-ofimport-ban-on-poultry-produce. Accessed on 20/07/2015.

Nigeria Bureau of Statistics 2016. Gross Domestic Product quarterly report, 2016.

Odunsi, A. A., Akande, T. O., and Rafiu T. A. 2008. Understanding Practical Poultry and Feed Mill Management. Ogbomoso, Ola Printers. Revised Edition. Pp 28-31.

Oladejo, J. O. 2014. Economic analysis of feed mill industry in Lagos state, Nigeria. International Journal of Research in Management, Economics and Commerce. 


\section{Okunlola}

Oyo State 2019. Local Governments of $\mathrm{O}$ y $\mathrm{O}$ $\mathrm{s} t$ a $\mathrm{t}$ e. Https://oyostate.gov.ng/ministryof-local-government-andchieftaincy-matters/detailedinformation-of-the-33-localgovernments-in-brief/. Accessed on 23/05/2019.
The Poultry Site 2016. Nigeria's ban on poultry imports - important lessons $\mathrm{f}$ o $\mathrm{r}$ $\mathrm{G} h$ a $\mathrm{n} \mathrm{a}$. Https://thepoultrysite.com/news/20 16/06/nigerias-ban-on-poultryimports-important-lessons-forGhana.Accessed on 14/04/2019.

Received: $4^{\text {th }}$ August, 2020

Accepted: $19^{\text {th }}$ November, 2020 